\title{
Effect of Storage Duration and Butyric Acid Supplementation to Egg Quality of Laying Hens in The Third Phase of Production
}

\author{
Rizki Palupi ${ }^{1}$,Fitri Novaliya Lubis $^{1}$, and Demila Syukrima ${ }^{1}$ \\ ${ }^{1}$ Department of Technology and Livestock Industry, Faculty of Agricultural, Universitas Sriwijaya
}

\begin{abstract}
This study was aimed at determining the effect of storage duration and butyric acid supplementation on egg quality of laying hens in the third phase of production. It used experimental method that employed Completely Randomized Factorial Design consisting of 2 factors; Factor A and Factor B. Factor A had 4 treatment levels of supplementation of butyric acid in diets; A0 (control treatment), A1 (0.175 g/ kg diets), A2 $(0.350 \mathrm{~g} / \mathrm{kg}$ diets $)$, and A3 (0.525 g/ kg diets), while Factor B consisted of 3 levels of storage duration including B1 (1 week), B2 (2 weeks), and B3 (3 weeks). Each factor had 4 replications and each replication or unit consisted of 10 laying hens. The observed variables included egg weight, albumen weight, and yolk weight. The results indicated that the supplementation of butyric acid has no significant effect on the decrease of egg weight, albumen weight and yolk weight. Duration of storage significantly affected to decrease egg weight, albumen weight, and yolk weight. It can be concluded that there was no significant interaction between administration of butyric acid and duration of storage to the egg quality but duration of storage was significantly influenced the egg quality of laying hens in the third phase of production.
\end{abstract}

\section{Introduction}

Eggs are one of the poultry-derived foods that contain complete and easily digested nutrients such as fats, proteins, amino acids, vitamins and minerals. The need for eggs continues to increase along with the increasing demand for animal protein needed by the society.Eggs may experience various conditions that can cause a decrease in quality and even cause damage both during harvesting, transportation to the market, and even during storage by consumers. There are still many consumers who do not know that storing eggs for too long can cause internal and external damages. During storage, the eggs undergo a process of evaporation of gases such as $\mathrm{CO}_{2}$ and $\mathrm{H}_{2} \mathrm{O}$ continuously which in turn causes their quality to get worse.

Egg quality is influenced by ingredients oflaying hens' feed containing high protein and fat content. This is because the higher the protein and fat in the feed, the better the quality

*Coresponding Author: palupiarda@yahoo.com 
of egg whites and egg yolks produced. The provision of additional feed to the hens aims to maintain egg quality. One kind of the natural feed ingredients given to chickens is organic acids (acidifier). Organic acids can be in the form of citric acid, lactic acid, butyric acid, propionic acid, and acetic acid, or a mixture of other organic acids [9]. Organic acid added to the chickens feed in this study was butyric acid. Acidifiers are useful in protecting feed from damage by microbes and fungi but also directly affect the improvement of feed digestibility of livestock. The mechanism of acidifier action is to improve digestibility by increasing enzymes activity, decreasing gastric $\mathrm{pH}$, and reducing pathogenic bacteria in the digestive tracts. The use of acidifier increases the absorption of food substances in the small intestine, so that the food substances needed for egg production can be absorbed optimally. Optimal absorption can improve the quality of laying chicken eggs.

Several studies have suggested that the addition of organic acids in rations can have a positive effect on egg quality. The addition of Averrhoa bilimbi juice in feed is able to improve the external quality of eggs especially egg weight, shell weight, shell thickness and egg shape index [15]. Averrhoa bilimbi contains high organic acid components such as citric acid which functions to reduce intestinal $\mathrm{pH}$ to inhibit microbial growth. The use of herbal medicine industrial waste and lactic acid bacteria (Lactobacillus $s p$.) as synbiotics in additive feed can improve the quality of egg yolks [16].

\section{Materials and Methods}

\subsection{Research Materials}

This study used 200 Lohman laying hens aged 75 weeks in the third phase of production. The chickens were divided into 4 treatments and 5 replications. Each of replication consisted of 10 chickens. Laying hens were placed on a battery cage $(45 \times 35 \times 60$ $\mathrm{cm}$ ) and each plot was occupied by 1 laying hen and equipped with a feed container and a drinking water container.

The equipment used in the study included scales (branded 'Tanita' with a capacity of 0 $2000 \mathrm{~g}$ ), tarpaulin for mixing rations, plastic for storing rations for 1 week, and analytical balancefor weighing the remaining feed and egg weight.

Feed ingredients used in preparing rations consisted of milled corn, concentrate, and bran. The rations were given as much as 120 grams per head per day. The rations were given every morning at 5:00 as much as $40 \%$ and at noon at 1:00 p.m. as much as $60 \%$. The nutritions contained crude protein of $19.38 \%$ and metabolizable energy of $2960 \mathrm{kkal} \mathrm{kg}^{-1}$.

Measurement of egg quality during storage was carried out at week 3. Four eggs were taken randomly at each replication of 4 treatments. The eggs were placed in the 4 egg trays and stored at room temperature. The measurement was carried out in accordance with the levels of storage treatment that are 1 week, 2 weeks, and 3 weeks.

\subsection{Research Method}

This research was carried out using experimental method using Completely Randomized Factorial Design consisting of 2 factors: factor A and factor B. Factor A was the treatment of giving levels of butyric acid to the rations, namely: R0 (without calcium butyrate), R1 (supplementation of $0.175 \mathrm{~g} / \mathrm{kg}$ of calcium butyrate), R2 (supplementation of $0.350 \mathrm{~g} / \mathrm{kg}$ of calcium butyrate), and R3 (supplementation of $0.525 \mathrm{~g} / \mathrm{kg}$ of calcium butyrate). Factor B was the length (time) of egg storage, namely: B1 (egg storage for 1 
week), B2 (egg storage for 2 weeks) and B3 (egg storage for 3 weeks). Parameters observed were egg weight $(\mathrm{g})$, egg white weight $(\mathrm{g})$ and egg yolk weight $(\mathrm{g})$ during the storage.

Data obtained during the study were analyzed statistically by analysis of variance according to the design used. If there are significant differences in treatment, further testing will be carried out with the Duncan Multiple Range Test (DMRT) according to [14].

\section{Results and Discussions}

\subsection{Egg Weight}

The average weights of Lohman laying hens' eggs in the third phase of production treated with addition of butyric acid in rations stored for 1 week, 2 weeks and 3 weeks are presented in Table 1 below.

Table 1. Egg weight after being storage (g)

\begin{tabular}{|c|c|c|c|c|c|}
\hline \multirow{2}{*}{$\begin{array}{c}\text { Storage } \\
\text { Duration }\end{array}$} & \multicolumn{4}{|c|}{ Butyric acid } & \multirow{2}{*}{ Average } \\
\cline { 2 - 5 } & $\mathrm{R} 0(0)$ & $\mathrm{R} 1(0.175)$ & $\mathrm{R} 2(0.350)$ & $\mathrm{R} 3(0.525)$ & \\
\hline 1 week & $71.2 \pm 1.9$ & $69.8 \pm 5.2$ & $70.2 \pm 3.9$ & $68.6 \pm 2.0$ & $69.9 \pm 3.4^{\mathrm{b}}$ \\
\hline 2 weeks & $68.2 \pm 2.4$ & $67.0 \pm 3.3$ & $67.0 \pm 4.5$ & $64.2 \pm 2.1$ & $66.6 \pm 3.3^{\mathrm{b}}$ \\
\hline 3 weeks & $64.8 \pm 3.7$ & $63.4 \pm 2.7$ & $63.8 \pm 3.9$ & $61.8 \pm 1.6$ & $63.4 \pm 3.0^{\mathrm{a}}$ \\
\hline Average & $68.1 \pm 7.2$ & $66.7 \pm 9.9$ & $67.0 \pm 12.1$ & $64.9 \pm 4.9$ & \\
\hline
\end{tabular}

Analysis of variance showed no interaction $(\mathrm{P}>0.05)$ between storage time and level of butyric acid administration. This shows that there is no difference in the effect of adding different butyric acid levels in the rations on egg weight during storage. Addition of butyric acid in the rations has not been able to optimize the $\mathrm{pH}$ of the digestive tract of laying hens so that the addition of butyric acid has not been able to increase the conversion of the pepsinogen enzyme to pepsin which serves to increase the rate of protein digestion into amino acids and minerals which can affect egg quality.Organic acids added in poultry rations can accelerate the process of changing pepsinogen to pepsin so as to increase the absorption rate of proteins, amino acids, minerals, and calcium [7]. According to [4], although all nutrients can be absorbed by the chicken's body, but these are used as energy to meet basic life needs, so that the energy that is used for egg formation is not optimal which then affects the weight of the eggs produced.

Storage duration had a significant effect $(\mathrm{P}<0.05)$ on egg weight. The results of further tests showed that the mean value of the weight of the eggs that were shrinking for storage for 1 week $(69.9 \mathrm{~g})$ was not significantly different $(\mathrm{P}>0.05)$ from storage for 2 weeks $(66.6$ g). Storage for 2 weeks was also not significantly different $(\mathrm{P}>0.05)$ from storage for 3 weeks $(63.4 \mathrm{~g})$, while storage for 1 week $(69.6 \mathrm{~g})$ was significantly different $(\mathrm{P}<0.05)$ from storage for 3 weeks $(63.4 \mathrm{~g})$. This was characterized by an enlarged air cavities and an increase in the $\mathrm{pH}$ of the eggsfrom 7 to $10-11$ so that there was a decrease in the egg weight during storage at room temperature. The occurrence of the process of gas exchange from inside the egg with the outside air of the egg through the shell pores such as $\mathrm{CO}_{2}, \mathrm{H}_{2} \mathrm{O}$ and the occurrence of liquefaction (thick albumen melted due to denatured glycoprotein) caused a decrease in weight of eggs that were stored longer. Therefore, the length of storage time can affect the quality of eggs, which is indicated by reduced egg weight.This is in accordance with [2] arguing that the longer the storage, the greater the depth of the air cavity which causes the shrinkage of the egg weight due to the evaporation of water and the release of gas that occurs during storage. [5] also had the same opinion that the decrease in 
egg weight during storage is marked by the increasing air cavity because of getting older, the egg loses fluid and its contents will shrink further due to evaporation of water and release of gas during storage. During storage, the egg will change its contents so that its quality will decrease [8]. [5] stated that stored eggs with a relative humidity of $80-90 \%$ were only able to survive for 14 days of storage. In accordance with the research of [11], egg quality will decrease during storage due to destruction of ovomucin which leads to the reduction of egg quality which results in decay.

\subsection{Egg White Weight}

The average weights of Lohman laying hens' egg white in the third phase of production treated with addition of butyric acid in rations stored for 1 week, 2 weeks and 3 weeks are presented in Table 2 below.

Table 2. Egg white weight after being stored (g)

\begin{tabular}{|c|c|c|c|c|c|}
\hline $\begin{array}{c}\text { Storage } \\
\text { Duration }\end{array}$ & \multicolumn{4}{|c|}{ Butyric Acid } & \multirow{2}{*}{ Average } \\
\hline & $\mathrm{R} 0(0)$ & $\mathrm{R} 1(0,175)$ & $\mathrm{R} 2(0,350)$ & $\mathrm{R} 3(0,525)$ & \\
\hline 1 week & $44.0 \pm 3.9$ & $41.0 \pm 5.5$ & $41.2 \pm 3.2$ & $40.4 \pm 2.9$ & $41.6 \pm 4.0^{\mathrm{b}}$ \\
\hline 2 weeks & $39.0 \pm 2.0$ & $39.2 \pm 4.3$ & $38.2 \pm 3.2$ & $38.4 \pm 2.8$ & $38.7 \pm 3.0^{\mathrm{b}}$ \\
\hline 3 weeks & $33.2 \pm 4.6$ & $36.6 \pm 2.3$ & $35.4 \pm 4.8$ & $34.8 \pm 2.7$ & $35.0 \pm 3.7^{\mathrm{a}}$ \\
\hline Average & $38.7 \pm 8.7$ & $38.9 \pm 11.8$ & $38.3 \pm 10.8$ & $27.8 \pm 7.1$ & \\
\hline
\end{tabular}

Analysis of variance showed no interaction $(\mathrm{P}>0.05)$ between storage time and levels of butyric acid administration. This shows that there was no difference in the effect of giving different levels to the poultry rations on egg white weight during storage. This is indicated by the longer the storage of eggs the more dilute the egg white produced. Absorption of all digestible feed contents that have no effect on egg white is presumably because all the proteins contained by the absorbed feed were utilized to meet the basic life needs of the hen that had begun to diminish, so that the absorption of protein for egg whites was insufficient. In contrast to [13] opinion that the administration of acetic acid as organic acid to laying hens can improve body weight which periodically improve egg weight and protein and calcium concentration in the blood at the age of 54-70 weeks.

Increased levels of butyric acid had no significant effect $(\mathrm{P}>0.05)$ on egg white weight during storage. The average weight of egg whites produced with levels of butyric acid of 0 $\mathrm{g}, 0.175 \mathrm{~g}, 0.350 \mathrm{~g}$, and $0.525 \mathrm{~g}$, were $38.7 \mathrm{~g}, 38.9 \mathrm{~g}, 38.3 \mathrm{~g}$ and $27.8 \mathrm{~g}$, respectively. This means that egg weight at the highest level of butyric acid of $0.525 \mathrm{~g}$ produced the lowest average egg white weight compared to the average produced at another level, while the average egg white weight produced by the control level was higher than the average weight produced by R2 level $(0.350 \mathrm{~g})$. This could occur because the weight of the egg white was affected by the protein contained by feed; the more the protein absorbed by the body for egg formation, the thicker the egg white is produced. This is what can maintain egg quality during storage.

Storage duration had a significant effect $(\mathrm{P}<0.05)$ on the quality of egg white weight. DMRT further test results showed that the mean egg white weight after storage for 1 week was not significantly different $(\mathrm{P}>0.05)$ from storage for 2 weeks, and storage for 2 weeks was not significantly different $(\mathrm{P}>0.05)$ from storage for 3 weeks, while storage for 1 week was significantly different $(\mathrm{P}<0.05)$ from storage for 3 weeks. These results indicated that in storage for 1 week to 2 weeks, significant evaporation of egg whites had not been seen, whereas evaporation of egg whites during 3 weeks of storage had occurred. This happened 
due to the evaporation process in the egg whites that occured during storage because the air bags were squeezed by the contents of the egg which made it experience a rapid dilation process which resulted in the egg white to be diluted [12] stated that the decrease in the thickness of egg whites during storage was caused by an increase in $\mathrm{pH}$ due to $\mathrm{CO}_{2}$ evaporation and ovomucin damage caused by damage to the gel structure due to physicochemical damage of ovomucin fibers which caused the release of water from the formed webs. Ovomucin is a fiber-shaped glycoprotein that can bind water in the form of a gel structure. Same with the opinion of [3], the decrease in egg white quality is caused by evaporation of water and $\mathrm{CO}_{2}$ gas from the contents of the egg so that the nature of the base of the egg white rises which in turn causes ovomucin fibers to become damaged and broken. Decreased egg quality is associated with changes in eggs during storage, one of which is caused by $\mathrm{H}_{2} \mathrm{O}$ evaporation which means reducing the moisture content of egg white as its largest constituent [6].

\subsection{Egg Yolk Weight}

The average weights of Lohman laying hens' egg yolk in the third phase of production treated with addition of butyric acid in rations stored for 1 week, 2 weeks and 3 weeks are presented in Table 3 below.

Table 3. Egg yolk weight after being stored (g)

\begin{tabular}{|c|c|c|c|c|c|}
\hline $\begin{array}{c}\text { Storage } \\
\text { Duration }\end{array}$ & \multicolumn{4}{|c|}{ Butyric Acid } & \multirow{2}{*}{ Average } \\
\hline & R0(0) & R1(0,175) & R2(0,350) & R3(0,525) & \\
\hline 1 week & $20.8 \pm 3.8$ & $18.6 \pm 2.4$ & $18.8 \pm 1.3$ & $17.8 \pm 1.6$ & $19.0 \pm 2.5$ \\
\hline 2 weeks & $17.6 \pm 2.0$ & $17.2 \pm 1.3$ & $17.2 \pm 3.2$ & $17.0 \pm 1.0$ & $17.6 \pm 2.0$ \\
\hline 3 weeks & $18.4 \pm 2.6$ & $16.6 \pm 1.5$ & $16.6 \pm 1.7$ & $16.6 \pm 1.1$ & $17.2 \pm 1.8$ \\
\hline Average & $18.9 \pm 4.1$ & $17.4 \pm 3.5$ & $18.2 \pm 5.7$ & $17.1 \pm 2.6$ & \\
\hline
\end{tabular}

Analysis of variance showed no interaction $(\mathrm{P}>0.05)$ between storage time and levels of butyric acid administration. This showed that there was no influence in giving different butyric acid levels in poultry rations on the quality of egg yolks during storage, the addition of butyric acid in the rations might not be able to balance the intestinal $\mathrm{pH}$ so that the rations given had not been absorbed properly by the chicken, this was caused by aged chicken. Absorption of fat of feedconsumed by chickens was used to meet the needs of body fat that had begun to decrease so that the formation of fat in the yolk was not perfect. [10] stated that the fat in the chicken's body and the eggs produced was influenced by the consumption of fats derived from feed.

Increased levels of butyric acid had no significant effect $(\mathrm{P}>0.05)$ on egg yolk weight during storage. The average yolk weight produced by the control level R0 $(0 \mathrm{~g})$ resulted in the highest average yellow weight compared to the average produced at other levels. This showed that the use of butyric acid in this study had not been able to produce a different egg yolk weight. This is presumably because butyric acid added in the rations had not been able to increase the absorption capacity of fats derived from feed consumed, so that the fat in the formation of egg yolks was not absorbed perfectly. Butyric acid was unable to absorb the protein in the rationsbecause the yolk weight was influenced by the fat and protein contained in the feed.

Storage duration did not have a significant effect $(\mathrm{P}>0.05)$ on the egg yolk weight. These results indicate that during storage, the yolk did not experience major changes because the yolk was centered and protected by egg white so that the yolk did not get too 
much outside influence during storage. Changes in egg yolks were not so significantdue to the transfer of water from egg whites to yolks during storage since the breakdown of protein in egg whited and vitelin membranes which protect the yolkswas also split so that the yolks experienced additional volume during storage due to water permeation from egg whites to the yolk which caused the yolks to become wider and easier to break.During storage the yolks did not experience major changes due to the position that is in the middle and protected by egg whites which makes them not too much affected by the outside air during the storage [6]. [1] stated that decreasing binding capacity and the weakening vitelin membrane can cause water to be transferred from whites to egg yolks, which results in the yolks being dilute and relatively flat so that the egg quality becomes lower. The process of evaporation of water from the albumen causes the transfer of water into the egg yolks and the elasticity of the vitelin membrane to decrease, so that the yolks enlarge and decrease in height [12].

\section{Conclusion}

Based on the results of this study, it can be concluded that there is no interaction between butyric acid administration and the storage duration on the quality of laying henseggs in the third phase of production. Addition of butyric acid in the rations does not affect the quality of laying hens eggs in the third phase of production during the storage.

\section{References}

1. Natsir, M.H., Sjofjan, O., Umam, K. danMunab, A. Rekayasa produksi dan pemanfaatan acidifier sebagai pakan unggas melalui teknologi proteksi enkapsulasi (Universitas Brawijaya, Malang, 2005)

2. Tristianti, I.A., Widodo, E.danHalim, N. J.NutrisiTernak 1, 1 (2014)

3. Wijaya, Y., Suprijatna, E., danKismiati, S. J.Peternakan Indonesia 19, 2 (2017)

4. Steel, R. G. D. dan Torrie, J. H. Prinsip dan Prosedur Statistik (Penerbit PT. Gramedia Pustaka Utama, Jakarta, 1995)

5. Kaya, H.A., Kaya, M., Gul. AndCelebi, S. J. Animal. Vet. Adv 12 (2013)

6. Istinganah, L., Mugiono, S., danIriyanti, N. .J.IlmiahPeternakan 1, 1 (2013)

7. Djaelani, M.A. J. Buletin Anatomi dan Fisiologi 24, 1 (2016)

8. Jazil, N., Hintono, A.danMulyani, S. J.AplikasiTeknologiPangan 1, 2 (2013)

9. Riawan.,Rianti. dan Nova, K..J. IlmiahPeternakan Terpadu 5, 1 (2017)

10. Harmayanda, P.O.A., Rosyidi, D., danSofjan, O. J-PAL 7, 1 (2016)

11. Jansah J, IrmansyahdanKusnadi. 32, 1 (2009)

12. Nugraheni, Z. M., Hintono, A., danMangisah, I. J. Animal Agricultur Journal 4, 1 (2015)

13. Argo, L. B., Tristiarti.,danMangisah, I. J. Animal AgriculturJurnal 2, 1 (2013) 
